\title{
Pengaruh Jumlah Udara Segar dan Pertukaran Udara Terhadap Kapasitas Beban Pendingin pada Ruang Operasi
}

\author{
Maryadi \\ Program Studi Teknik Mesin, Fakultas Sains dan Teknologi, \\ Universitas Islam As-Syafi' iyah \\ Jl. Raya Jatiwaringin No. 12 Pondok Gede, Jakarta Timur 13070 \\ E-mail: adimaryadi77@yahoo.com
}

\begin{abstract}
Abstrak - Ruang operasi merupakan suatu ruangan yang ada di sebuah rumah sakit, ruangan tersebut mempunyai kekhususan dibandingkan dengan ruangan yang lain pada suatu rumah sakit. Ruang operasi adalah ruang yang sangat penting karena aktifitas di dalamnya secara langsung menyangkut nyawa manusia. Kekhususan tersebut diantaranya pada sistem tata udaranya harus sesuai dengan Pedoman Teknis Bangunan Rumah Sakit Ruang Operasi dari Kementerian Kesehatan Republik Indonesia Tahun 2012. Beberapa poin penting yang terkandung dalam peraturan tersebut adalah tekanan di dalam ruang operasi harus positif dibanding dengan tekanan di luar ruang operasi dengan memasok udara lebih dari 15\%. Temperatur ruang operasi dijaga antara $19{ }^{\circ} \mathrm{C}$ sampai dengan $24{ }^{\circ} \mathrm{C}$ dan kelembaban relatif udara harus dijaga antara $50 \%$ sampai dengan $60 \%$. Dengan tujuan mencari nilai optimal kapasitas beban pendingin pada ruang operasi dengan jumlah udara segar sesuai yang dibutuhkan, akan menggunakan bantuan software HAP 4.90. Data jumlah udara segar dan jumlah pertukaran udara akan dimasukkan kedalam software, setelah itu software akan simulasi dan keluar hasilnya. Kapasitas beban pendingin tertinggi 151,3 $\mathrm{kW}$ terjadi pada jumlah udara segar $100 \%$ dan jumlah pertukaran udara 50 ACH (jumlah pertukaran udara per jam), sedangkan kapasitas beban pendingin terendah 43,4 $\mathrm{kW}$ terjadi pada jumlah udara segar $40 \%$ dan jumlah pertukaran udara 30 ACH. Sehingga semakin kecil jumlah udara segar dan jumlah pertukaran udara yang semakin kecil, akan didapatkan kapasitas beban pendingin yang rendah. Begitu juga sebaliknya semakin besar jumlah udara segar dan jumlah pertukaran udara yang semakin besar, akan didapatkan kapasitas beban pendingin yang tinggi.
\end{abstract}

Kata kunci : udara segar, pertukaran udara, ruang operasi.

\section{PENDAHULUAN}

Seiring dengan perkembangan jaman banyak sekali timbul berbagai macam penyakit yang ditimbulkan oleh berbagai faktor, sehingga banyak dibangun rumah sakit. Pada sebuah rumah sakit biasanya sudah dilengkapi dengan ruang operasi, ruang operasi merupakan suatu ruangan yang ada di sebuah rumah sakit, ruangan tersebut mempunyai kekhususan dibandingkan dengan ruangan yang lain pada suatu rumah sakit. Ruang operasi adalah ruang yang sangat kritikel karena aktifitas di dalamnya secara langsung menyangkut nyawa manusia.

Kekhususan tersebut diantaranya pada sistem tata udaranya harus sesuai dengan Pedoman Teknis Bangunan Rumah Sakit Ruang Operasi dari Kementerian Kesehatan Republik Indonesia Tahun 2012. Beberapa poin penting yang terkandung dalam peraturan tersebut adalah tekanan di dalam ruang operasi harus positif dibanding dengan tekanan di luar ruang operasi dengan memasok udara lebih dari $15 \%$. Temperatur ruang operasi dijaga antara $19{ }^{\circ} \mathrm{C}$ sampai dengan $24{ }^{\circ} \mathrm{C}$ dan kelembaban relatif udara harus dijaga antara 50\% sampai dengan 60\%. [1]

Untuk menjaga tekanan dan kesegaran di dalam ruang operasi maka, dibutuhkan suplai udara segar dari luar ruangan. Kebutuhan udara segar berbeda - beda dari 30\% sampai dengan $100 \%$ dari kapasitas suplainya. Seberapa besar udara segar yang dimasukkan akan berpengaruh terhadap perhitungan kapasitas beban pendingin. [2], [3]

Untuk menjaga kesegaran udara di dalam ruang operasi agar tidak pengap maka, diperlukan pertukaran udara yang cukup sesuai kebutuhan. Jumlah pertukaran udara di dalam ruang operasi juga akan mempengaruhi perhitungan beban pendingin. Berdasarkan peraturan jumlah pertukaran udara di ruang operasi minimal 25 kali pertukaran udara. [1] 
Semakin besar jumlah udara segar yang dimasukkan ke dalam ruang operasi dan jumlah pertukaran udara di dalam ruang operasi maka, semakin besar juga kapasitas beban pendinginnya. Begitu juga sebaliknya semakin kecil jumlah udara segar yang dimasukkan ke dalam ruang operasi dan jumlah pertukaran udara di dalam ruang operasi maka, semakin kecil juga kapasitas beban pendinginnya.

Untuk mengetahui seberapa besar pengaruh antara jumlah udara segar yang dimasukan ke dalam ruang operasi dan jumlah pertukaran udara di dalam ruang operasi secara teliti maka, dibutuhkan suatu perhitungan menggunakan software.

\section{LANDASAN TEORI}

Psikrometrik chart merupakan alat yang digunakan untuk mempelajari mengenai sifat - sifat dan karakteristik udara, dengan menggunakan chart ini orang tidak perlu menggunakan hitungan matematis yang rumit, karena dengan chart ini perencanaan sistem tata udara menjadi lebih sederhana. Secara grafik mengenai sifat termodinamika udara ditampilkan pada psikrometrik chart seperti kelembaban, temperatur, enthalpi, volume spesifik dan kandungan uap air. Parameter udara secara cepat dan presisi bisa langsung dilihat pada psikrometrik chart ini, baik yang berhubungan dengan sifat termal udara atau sifat fisiknya. [4], [5]

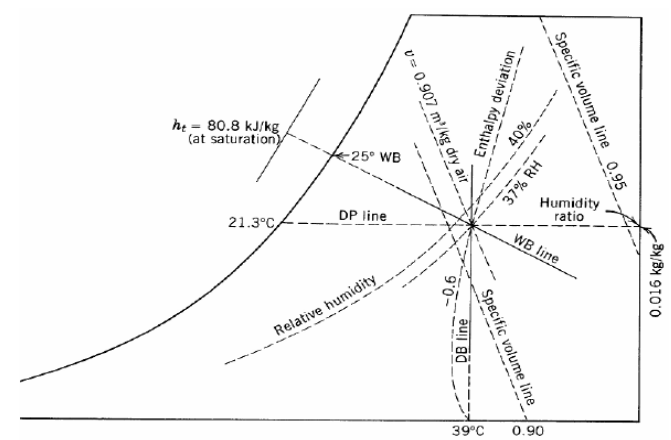

\section{Gambar 1 Pemetaan Garis Skala Psikrometrik Chart.}

Berikut adalah tujuh parameter tentang udara yang terpenting yang digunakan dalam perancangan sistem tata udara yang pertama adalah Dry bulb Temperature (DB) yaitu pengukuran suhu udara ruang yang diperoleh dengan menggunakan slink psikrometer pada termometer dengan bola kering. Suhu DB terdapat pada garis vertikal yang berawal dari garis sumbu mendatar yang terletak dibagian bawah chart.

Yang kedua adalah Wet bulb Temperature (WB) yaitu pengukuran suhu udara ruang yang diperoleh dengan menggunakan slink psikrometer pada termometer dengan bola basah. Suhu WB terdapat pada garis miring ke bawah yang berawal dari garis saturasi yang terletak dibagian samping kanan chart. Yang ketiga adalah Dew point Temperature (DP) yaitu suhu dimana udara mulai menunjukkan pengembunan pada saat didinginkan. Suhu DP terdapat pada garis sepanjang garis saturasi. Yang keempat adalah Specific Humidity (W) yaitu jumlah kandungan uap air di udara yang diplotkan pada garis sumbu vertikal yang ada dibagian samping kanan chart.

Yang kelima adalah Relative Humidity (RH) yaitu merupakan perbandingan jumlah aktual dan jumlah maksimal dari uap air yang ada pada suatu ruang tertentu. Garis RH diplotkan pada garis melengkung dari sisi sebelah kiri ke sisi sebelah kanan. Yang keenam adalah Enthalpi $(\mathrm{H})$ yaitu jumlah panas total dari campuran udara dan uap air yang diplotkan pada garis sepanjang skala di atas garis saturasi. Yang ketujuh adalah Specific Volume $(\mathrm{SpV})$ yaitu kebalikan dari berat jenis, garis skalanya sama dengan garis skala bola basah. [4]

Salah satu proses yang sering dijumpai dalam perancangan sistem tata udara adalah percampuran dua atau lebih aliran udara yang mempunyai keadaan yang berbeda. Kondisi terakhir percampuran udara tersebut ditentukan oleh keseimbangan massa dan energi.

Untuk mengetahui temperatur udara campuran dapat menggunakan rumus (1), dimana $T_{c}$ adalah temperatur udara akhir, $\mathrm{T}_{\mathrm{a}}$ adalah temperatur udara satu, $\mathrm{T}_{\mathrm{b}}$ adalah temperatur udara dua, $\mathrm{m}_{\mathrm{a}}$ adalah massa udara satu, $m_{b}$ adalah massa udara dua dan $m_{c}$ adalah massa udara akhir. [4], [6]

$$
T_{c}=\frac{(m a)(T a)+(m b)(T b)}{m c}
$$

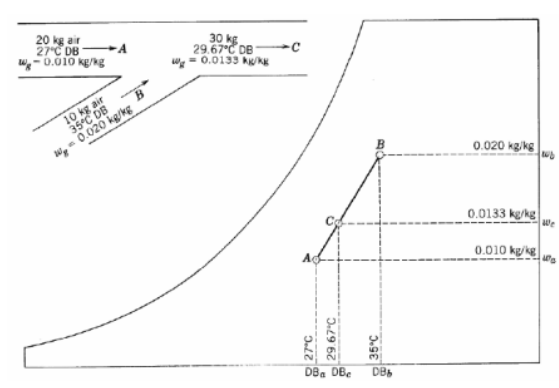

Gambar 2 Ilustrasi Percampuran Udara. 
Menghitung beban panas total adalah dengan rumus (2), dimana $\mathrm{Q}_{\mathrm{T}}$ adalah panas total, $\mathrm{m}$ adalah massa udara, $\mathrm{c}_{\mathrm{p}}$ adalah kapasitas panas spesifik udara, $h_{a}$ adalah entalpi pada kondisi satu dan $h_{b}$ adalah entalpi pada kondisi dua.

$$
Q_{T}=m x c_{p} x\left(h_{b}-h_{a}\right)
$$

Menghitung beban panas sensibel adalah dengan rumus (3), dimana $\mathrm{Q}_{\mathrm{s}}$ adalah panas sensibel, $m$ adalah massa udara, $c_{p}$ adalah kapasitas panas spesifik udara, $\mathrm{T}_{\mathrm{a}}$ adalah suhu pada kondisi satu dan $\mathrm{T}_{\mathrm{b}}$ adalah suhu pada kondisi dua.

$$
Q_{S}=m x c_{p} x\left(T_{b}-T_{a}\right)
$$

Menghitung beban panas laten adalah dengan rumus (4), dimana $\mathrm{Q}_{\mathrm{L}}$ adalah beban panas laten, $\mathrm{Q}_{\mathrm{T}}$ adalah beban panas total dan $\mathrm{Q}_{\mathrm{S}}$ adalah beban panas sensibel. [4]

$$
Q_{L}=Q_{T}-Q_{S}
$$

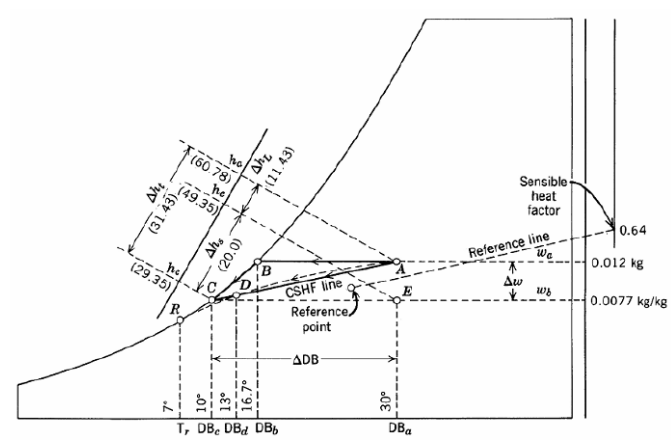

Gambar 3 Ilustrasi Proses Pendinginan

\section{METODOLOGI PENELITIAN}

Sistematika penelitian merupakan suatu diagram alir yang digunakan dalam proses penelitian. Adapun sistematika penelitian yang berjudul "Pengaruh Jumlah Udara Segar dan Pertukaran Udara Terhadap Kapasitas Beban Pendingin pada Ruang Operasi” berdasarkan tahapan dalam diagram alir sebagai berikut :

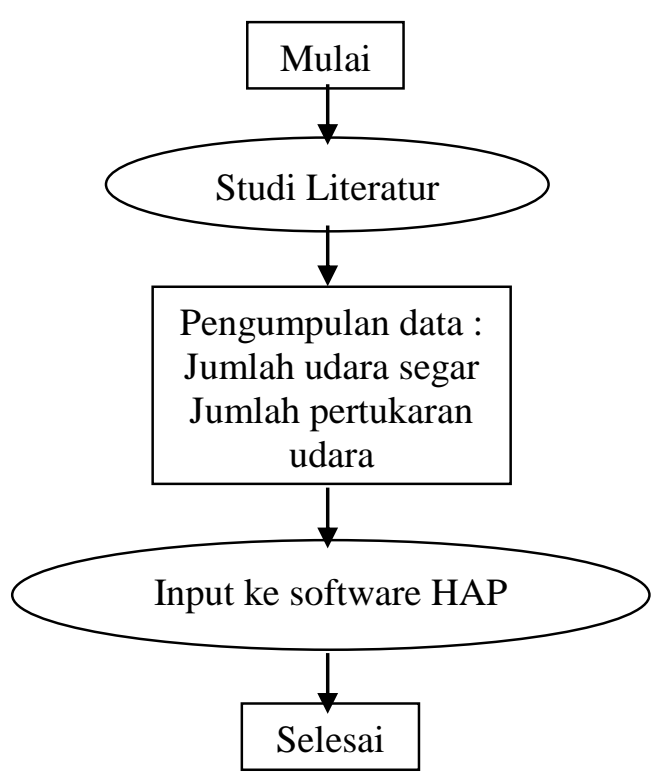

Gambar 4 Diagram Alir Proses Penelitian.

\subsection{Studi Literatur}

Studi literatur dapat dilakukan dengan mengumpulkan semua data yang berhubungan dengan kebutuhan udara segar dan jumlah pertukaran udara pada ruang operasi. Hal ini bertujuan untuk mendapatkan informasi yang berguna untuk perhitungan ini. Informasi dapat ditemukan dari internet, jurnal penelitian, buku dan konsultan perencana.

\subsection{Pengumpulan Data}

Dari tahap studi literatur akan mendapatkan data - data yang bisa diolah untuk perhitungan masukan ke program. Data - data bangunan yang dibutuhkan adalah luas ruang operasi, tinggi ruangan, peralatan listrik yang digunakan dan lampu penerangan pada ruang operasi serta peralatan lain yang dapat menimbulkan beban. Untuk luas dan tinggi ruang operasi bisa diperoleh dari konsultan arsitek, sedangkan untuk peralatan listrik di dalam ruang operasi bisa diperoleh dari pemilik rumah sakit. Dalam perhitungan ini akan menggunakan variasi jumlah udara segar $40 \%, 60 \%$, $80 \%$ dan $100 \%$, sedangkan untuk jumlah pertukaran udaranya $30 \mathrm{ACH}, 40 \mathrm{ACH}$ dan $50 \mathrm{ACH}$ Variasi jumlah udara segar dan pertukaran udara diatas merupakan data yang sering digunakan pada ruang operasi. 


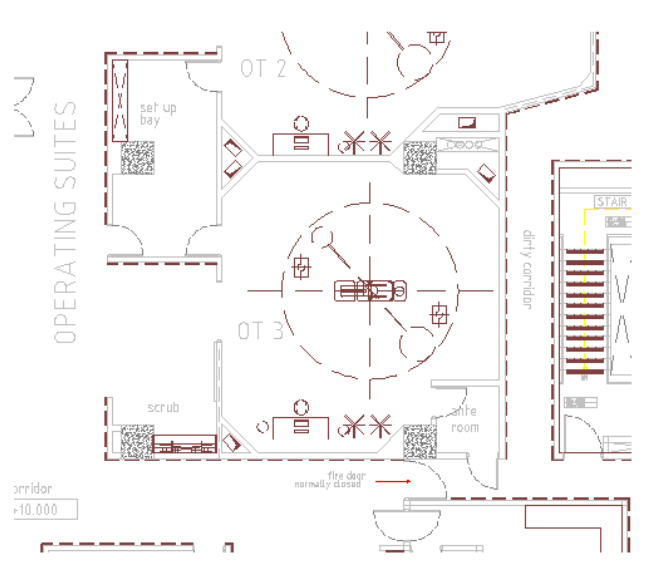

Gambar 5 Denah Arsitek Ruang Operasi.

\subsection{Perhitungan}

Untuk perhitungan beban pendingin menggunakan software HAP 4.90. Dengan memasukan data - data diantaranya jumlah udara segar dan jumlah pertukaran udara yang digunakan ke software tersebut maka, akan didapatkan kapasitas beban pendingin yang dibutuhkan dan diketahui pengaruh jumlah udara segar dan jumlah pertukaran udara dan data lainnya terhadap kapasitas beban pendingin.

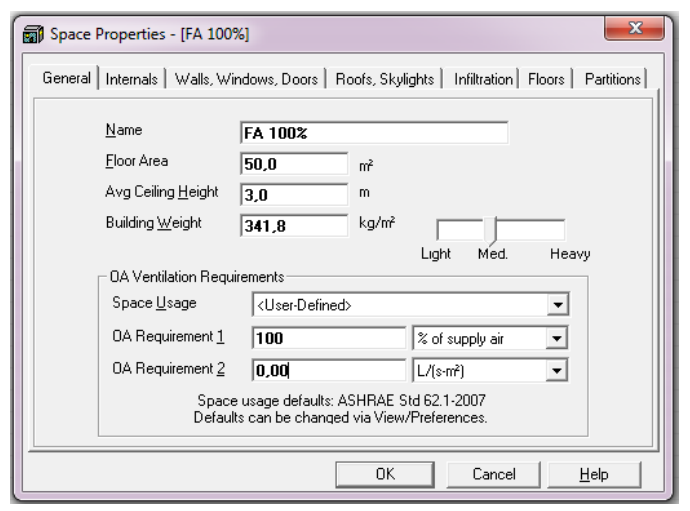

Gambar 6 Tampilan Software HAP 4.90 untuk Luas Ruangan.

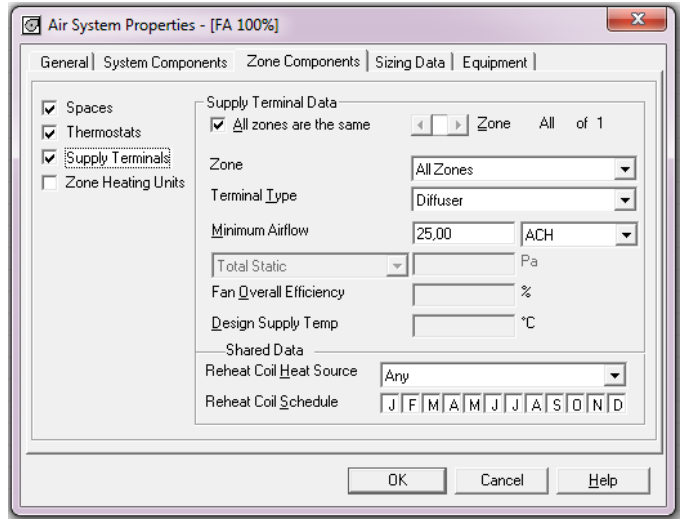

Gambar 7 Tampilan Software HAP 4.90 untuk Jumlah Pertukaran Udara.

\section{HASIL DAN PEMBAHASAN}

Tabel 1. dibawah adalah hasil dari perhitungan beban pendingin dengan menggunakan data beberapa jumlah udara segar yang berbeda. Terlihat bahwa pada jumlah udara segar yang sama sedangkan jumlah udara segar yang berbeda terdapat kenaikan kapasitas beban pedingin dengan jumlah udara segar yang semakin besar. Sedangkan pada jumlah pertukaran udara yang sama dengan jumlah udara segar yang berbeda juga ada kenaikkan kapasitas beban pendingin pada saat jumlah udara segar semakin tinggi.

Tabel 1 Hasil Perhitungan Beban Pendingin

\begin{tabular}{|c|c|c|r|}
\hline No. & $\begin{array}{c}\text { Jumlah } \\
\text { Udara } \\
\text { Segar } \\
(\boldsymbol{\%})\end{array}$ & $\begin{array}{c}\text { Jumlah } \\
\text { Pertukaran } \\
\text { Udara }\end{array}$ & $\begin{array}{c}\text { Kapasitas } \\
\text { Beban } \\
\text { Pendingin } \\
(\mathbf{k W})\end{array}$ \\
\hline 1 & 100 & 30 & 89,6 \\
\hline 2 & 100 & 40 & 120,4 \\
\hline 3 & 100 & 50 & 151,3 \\
\hline 4 & 80 & 30 & 73,2 \\
\hline 5 & 80 & 40 & 98,6 \\
\hline 6 & 80 & 50 & 124,1 \\
\hline 7 & 60 & 30 & 56,7 \\
\hline 8 & 60 & 40 & 76,9 \\
\hline 9 & 60 & 50 & 96,9 \\
\hline 10 & 40 & 30 & 43,4 \\
\hline 11 & 40 & 40 & 57,2 \\
\hline 12 & 40 & 50 & 70,9 \\
\hline
\end{tabular}


Berdasarkan grafik di gambar 8 merupakan grafik untuk udara segar $100 \%$, grafik tersebut menggambarkan hasil perhitungan dari software antara kapasitas beban pendingin dengan jumlah pertukaran udara. Pada grafik tersebut tergambarkan bahwa semakin banyak pertukaran udara maka, kapasitas beban pendingin semakin bertambah besar. Untuk jumlah pertukaran udara $30 \mathrm{ACH}$ didapat kapasitas beban pendingin sebesar 89,6 $\mathrm{kW}$ dan untuk jumlah pertukaran udara $40 \mathrm{ACH}$ didapat kapasitas beban pendingin sebesar $120,4 \mathrm{~kW}$, sedangkan untuk jumlah pertukaran udara $50 \mathrm{ACH}$ didapat kapasitas beban pendingin sebesar $151,3 \mathrm{~kW}$.

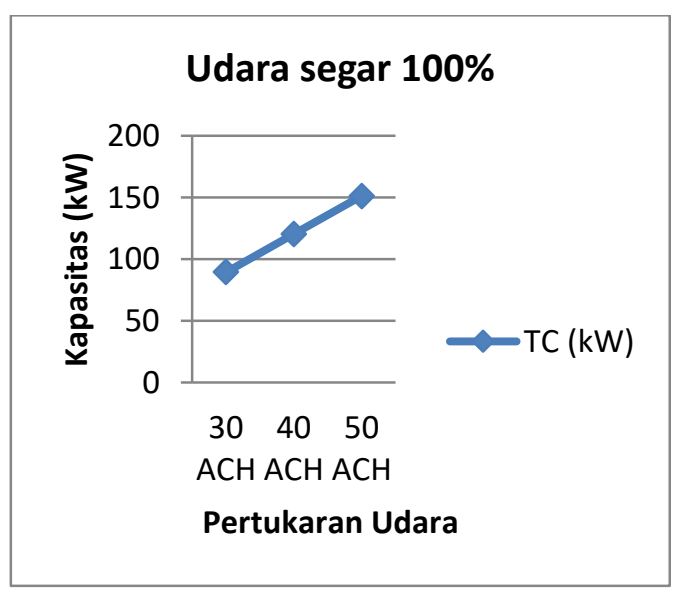

Gambar 8 Grafik Antara Kapasitas Beban Pendingin dengan Jumlah Pertukaran Udara pada Udara Segar $100 \%$.

Berdasarkan grafik di gambar 9 merupakan grafik untuk udara segar $80 \%$, grafik tersebut menggambarkan hasil perhitungan dari software antara kapasitas beban pendingin dengan jumlah pertukaran udara. Pada grafik tersebut tergambarkan bahwa semakin banyak pertukaran udara maka, kapasitas beban pendingin semakin bertambah besar. Untuk jumlah pertukaran udara $30 \mathrm{ACH}$ didapat kapasitas beban pendingin sebesar 73,2 kW dan untuk jumlah pertukaran udara $40 \mathrm{ACH}$ didapat kapasitas beban pendingin sebesar 98,6 kW, sedangkan untuk jumlah pertukaran udara 50 ACH didapat kapasitas beban pendingin sebesar $124,1 \mathrm{~kW}$.

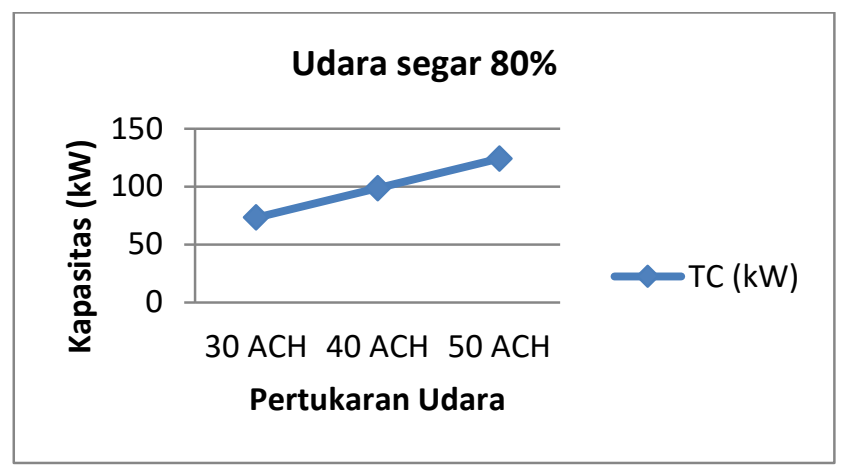

\section{Gambar 9 Grafik Antara Kapasitas Beban Pendingin dengan Jumlah Pertukaran Udara pada Udara Segar $80 \%$.}

Berdasarkan grafik di Gambar 10 merupakan grafik untuk udara segar $60 \%$, grafik tersebut menggambarkan hasil perhitungan dari software antara kapasitas beban pendingin dengan jumlah pertukaran udara. Pada grafik tersebut tergambarkan bahwa semakin banyak pertukaran udara maka, kapasitas beban pendingin semakin bertambah besar. Untuk jumlah pertukaran udara $30 \mathrm{ACH}$ didapat kapasitas beban pendingin sebesar $56,7 \mathrm{~kW}$ dan untuk jumlah pertukaran udara $40 \mathrm{ACH}$ didapat kapasitas beban pendingin sebesar $76,9 \mathrm{~kW}$, sedangkan untuk jumlah pertukaran udara 50 ACH didapat kapasitas beban pendingin sebesar $96,9 \mathrm{~kW}$.

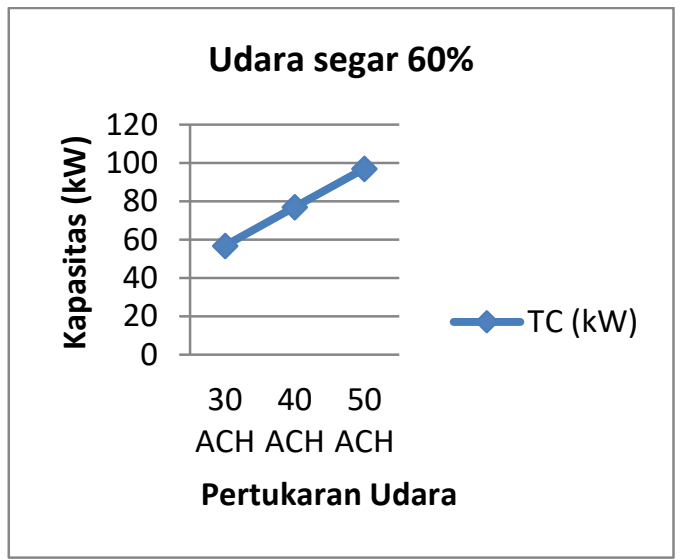

Gambar 10 Grafik Antara Kapasitas Beban Pendingin dengan Jumlah Pertukaran Udara pada Udara Segar $60 \%$. 
Berdasarkan grafik di Gambar 11 merupakan grafik untuk udara segar $40 \%$, grafik tersebut menggambarkan hasil perhitungan dari software antara kapasitas beban pendingin dengan jumlah pertukaran udara. Pada grafik tersebut tergambarkan bahwa semakin banyak pertukaran udara maka, kapasitas beban pendingin semakin bertambah besar. Untuk jumlah pertukaran udara $30 \mathrm{ACH}$ didapat kapasitas beban pendingin sebesar $43,4 \mathrm{~kW}$ dan untuk jumlah pertukaran udara $40 \mathrm{ACH}$ didapat kapasitas beban pendingin sebesar $57,2 \mathrm{~kW}$, sedangkan untuk jumlah pertukaran udara 50 $\mathrm{ACH}$ didapat kapasitas beban pendingin sebesar $70,9 \mathrm{~kW}$.

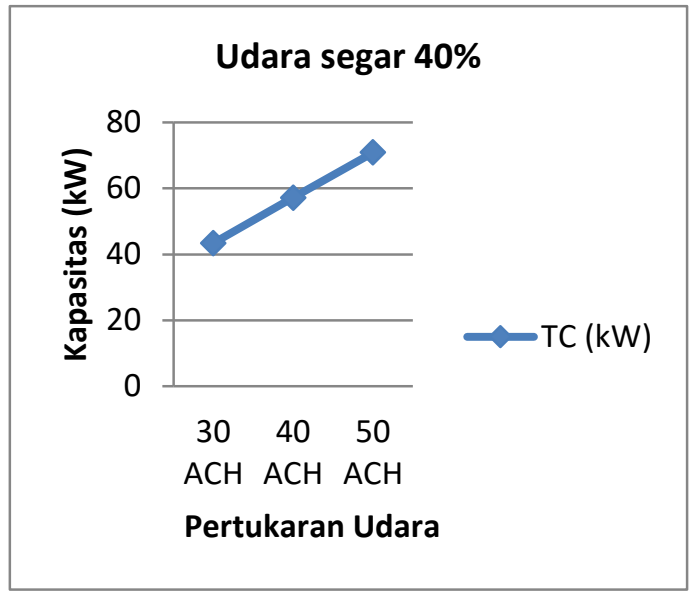

Gambar 11 Grafik Antara Kapasitas Beban Pendingin dengan Jumlah Pertukaran Udara pada Udara Segar $40 \%$.

\section{SIMPULAN}

Sesuai hasil penelitan diatas didapatkan bahwa pada jumlah udara segar yang sama sedangkan jumlah pertukaran udara yang berbeda terdapat kenaikan kapasitas beban pedingin dengan jumlah pertukaran udara yang semakin besar.

Sedangkan pada jumlah pertukaran udara yang sama dengan jumlah udara segar yang berbeda juga ada kenaikkan kapasitas beban pendingin pada saat jumlah udara segar semakin besar. Sehingga semakin kecil jumlah udara segar dan jumlah pertukaran udara yang semakin kecil, akan didapatkan kapasitas beban pendingin yang rendah.

Begitu juga sebaliknya semakin besar jumlah udara segar dan jumlah pertukaran udara yang semakin besar, akan didapatkan kapasitas beban pendingin yang tinggi. Berdasarkan peraturan dengan menggunakan pertukaran udara $30 \mathrm{ACH}$ dan jumlah udara segar $40 \%$ sudah memenuhi persyaratan.

\section{KEPUSTAKAAN}

[1] Kementerian Kesehatan RI, 2012. Pedoman Teknis Bangunan Rumah Sakit Ruang Operasi. Direktorat Bina Pelayanan Penunjang Medik dan Sarana Kesehatan, Jakarta, 2012.

[2] ASHRAE GRP 158. Infiltrasi and Ventilation, New York, 1999.

[3] ASHRAE Standard 6.2.1-2004. Ventilation For Acceptable Indoor Air Quality, New York, 2004.

[4] Syamsuri H., dkk. Sistem Refrigerasi dan Tata Udara, Direktorat Pembinaan Sekolah Menengah Kejuruan. Departemen Pendidikan Nasional, Jakarta, 2008.

[5] W. Arismunandar dan H. Saito, Penyegaran Udara, cetakan 4, PT. Pradnya Paramita, Jakarta, 1998.

[6] A. Haryanto, Perpindahan Panas, Innosain, Yogyakarta, 2015.

[7] E. F. Stoecker, J. W. Jones, Refrigerasi dan Pengkondisian Udara, Erlangga, Jakarta, 1989.

[8] Carrier Air Conditioning Company. Handbook of Air Conditioning System Design, New York, 1965. 